\title{
Analisis Perhitungan Harga Pokok Produksi pada Mitra Mandiri Aluminium
}

\author{
${ }^{1}$ Tasman S Haris dan ${ }^{2}$ Misnawati \\ ${ }^{1}$ Dosen Universitas Lakidende \\ ${ }^{2}$ Dosen Universitas Lakidende \\ Correspondence email: tasmansharis@yahoo.com dan misnamisnawati61@gmail.com
}

\begin{abstract}
Abstrak: Penelitian bertujuan untuk mengetahui harga pokok produksi dengan menggunakan metode full bodyed dan variabel variabel. Situs penelitian untuk perusahaan mitra aluminium independen di jalan. Umum. Sudirman, kel. Ambekaeri, distrik unaaha. Metode yang digunakan adalah wawancara, dan dokumenter, sedangkan analisis yang digunakan adalah analisis deskriptif, yaitu metode penelitian dengan mengumpulkan data menurut apa adanya kemudian disusun dan dianalisis untuk memberikan gambaran tentang masalah. Hasil penelitian menunjukkan bahwa terdapat ketidaksesuaian harga pokok secara penuh sesuai dengan metode non-linier, dan metode variabel, karena perbedaan biaya biaya, metode variabel hanya menghitung variabel bop. Sedangkan kemiringan penuh akan membuat semua bop aktif dan bervariasi. Oleh karena itu, metode full bodyed lebih menguntungkan perusahaan karena membebankan semua biaya yang mempengaruhi proses produksi, sehingga menghasilkan harga produksi yang lebih akurat.
\end{abstract}

Kata kunci: biaya dan pokok produksi.

Abstrak : Research aims to find out the underlying price of production using full bodied methods and variable variables. The research site for the aluminum independent partner company on street. General. Sudirman, kel. Ambekaeri, unaaha district. The method used is interviews, and documentaries, while the analysis used is a descriptive analysis, which is the method of research by collecting data according to what they are and then getting it prepared and analyzed to give an idea of the problem. The results of the study indicate that there are discrepancies in the price of the subject in full accordance with the non-linear method, and the variable method, because of the difference in cost cost, the variable method calculates only the bop variables. Whereas the full tilt would render all the bop active and variable. Therefore, full bodied methods benefit the company more because they impose all costs that affect the production process, resulting in a more accurate production price.

Key words: cost and principal production.

\section{PENDAHULUAN}

Kemajuan dunia usaha jauh berkembang dengan pesat, baik dalam skala besar maupun kecil dan juga perkembangan di sektor industri yang memiliki peran penting dalam sektor perekonomian. Banyaknya industri yang terus bermunculan mengakibatkan timbulnya suatu persaingan di antara industri sejenis. Perusahaan-perusahaan atau industri-industri itu didirikan dan beroperasi dengan suatu tujuan atau rencana yang akan dicapai. Dari sekian banyak tujuan tersebut, yang paling utama adalah mendapatkan keuntungan atau laba. Demikian dengan perusahaan kecil dan menengah yang menghasilkan sesuatu untuk memperoleh keuntungan atau laba.

Penentuan harga pokok produksi merupakan hal yang sangat penting mengingat manfaat informasi harga pokok produksi adalah untuk menentukan harga jual produk, pemantauan realisasi biaya produksi, perhitungan laba rugi periodik serta penentuan harga pokok persediaan produk jadi dan produk dalam proses yang disajikan dalam neraca. Dalam perhitungan harga pokok produksi, informasi yang dibutuhkan adalah informasi mengenai biaya bahan baku, biaya tenaga kerja, dan biaya overhead pabrik. Ketiga jenis biaya tersebut harus ditentukan secara cermat, baik dalam pencatatan maupun penggolongannya. Pada metode Full costing semua biaya-biaya diperhitungkan baik yang bersifat tetap maupun variabel karena salah satu cara pengendalian biaya yaitu dengan menghitung harga pokok produksi untuk menentukan harga jual produk itu sendiri. Sedangkan metode variabel costing merupakan metode penentuan harga pokok produksi yang mengelompokan biaya berdasarkan perilaku biaya. yang terdiri dari biaya bahan baku, biaya tenaga kerja langsung, dan biaya overhead pabrik variabel. Dalam metode variabel costing untuk penentuan harga 
pokok produksi hanya biaya-biaya produksi variabel saja yang dimasukan dalam persedian dan biaya pokok penjualan.

Mitra Mandiri Aluminium adalah usaha manufaktur yang melakukan aktivitas produksinya dengan membeli bahan mentah lalu memperosesnya menjadi barang jadi dan menjual barang jadi tersebut. Jenis produk yang dihasilkan oleh Mitra Mandiri Aluminium seperti Kusen aluminium, Jendela aluminium, Lemari baju, Rak piring, Kitchen set, dan Rolling dor. Mitra Mandiri Aluminium ini dalam menentukan perhitungan harga pokok produksinya tidak menggunakan pencatatan transaksi yang sesuai dengan kaidah akuntansi atau masih menggunakan pencatatan yang sederhana/ tradisional sehingga tidak bisa menentukkan figur harga pokok produksi. Pemilik juga menyampaikan bahwa penentuan harga pokok produksi biayabiaya yang diperhitungkan terdiri dari biaya pembelian bahan baku baku berupa kaca, stenlis alat perekat dan lain-lain

Sofia, et al (2015:21) harga pokok produksi adalah biaya barang yang dibeli untuk diproses sampai selesai, baik sebelum maupun selama periode akuntansi berjalan. Semua biaya ini adalah biaya persediaan. Biaya persediaan yaitu semua biaya produk yang dianggap sebagai aktiva dalam neraca ketika terjadi dan selanjutnya menjadi harga pokok penjualan ketika produk itu dijual.

Penetapan harga pokok produksi yang tepat sangat penting bagi perusahaan dalam menjalankan usahanya. Terdapat dua kemungkinan yang akan ditemui jika perusahaan tidak teliti dalam melakukan perhitungan harga pokok produksi, Rendahnya harga pokok yang ditetapkan dapat merugikan perusahaan itu sendiri karena harga pokok yang rendah akan menyebabkan harga jualnya pun menjadi rendah.

\section{LANDASAN TEORI}

\section{Biaya}

Pada dasarnya biaya adalah pengorbanan ekonomi yang dikeluarkan, dapat diukur dan ditaksir jumlahnya. Ada beberapa pengertian biaya menurut para pakarnya, seperti yang dikemukakan oleh Mulyadi pengertian biaya merupakan pengorbanan sumber ekonomi yang diukur dalam satuan uang, yang telah terjadi atau kemungkinan akan terjadi untuktujuan tertentu.

Bahan baku terbagi menjadi dua yaitu bahan baku langsung dan bahan baku tidak langsung. Bahan baku langsung merupakan bahan-bahan yang dapat secara mudah dan akurat ditelusuri ke produk jadi dan siap jual. Sedangkan bahan baku tidak langsung adalah bahan baku yang tidak dapat secara mudah dan akurat ditelusuri ke produk jadi dan siap jual. (Putra, 2018:119)

Menurut Mulyadi (2014) dalam perusahaan yang berproduksi massa, informasi harga pokok produksi yang dihitung untuk jangka waktu tertentu bermanfaat bagi manajemen untuk :

1. Menentukan harga jual

Perusahaan yang berproduksi massa memproses produknya untuk memenuhi persediaan di gudang. Dengan demikian biaya produksi dihitung untuk jangka waktu tertentu untuk menghasilkan informasi biaya produksi per satuan produk. Dalam penetapan harga jual produk, biaya produksi per unit merupakan salah satu informasi yang dipertimbangkan disamping informasi biaya lain serta informasi nonbiaya.

2. Memantau realisasi biaya produksi

Jika rencana produksi untuk jangka waktu tertentu telah diputuskan untuk dilaksanakan, manajemen memerlukan informasi biaya produksi yang sesungguhnya dikeluarkan di dalam pelaksanaan rencana produksi tersebut. Oleh karena itu akuntansi biaya digunakan untuk mengumpulkan informasi biaya produksi yang dikeluarkan dalam jangka waktu tertentu untuk memantau apakah proses produksi mengkonsumsi total biaya produksi sesuai dengan yang diperhitungkan sebelumnya.

3. Menghitung laba atau rugi bruto periode tertentu 
Untuk mengetahui apakah kegiatan produksi dan pemasaran perusahaan dalam periode tertentu mampu menghasilkan laba bruto atau mengakibatkan rugi bruto, manajeman memerlukan informasi biaya produksi yang telah dikeluarkan untuk memproduksi produk dalam periode tertentu. Informasi laba atau rugi bruto periodik diperlukan untuk mengetahui kontribusi produk dalam menutup biaya nonproduksi dan menghasilkan laba atau rugi.

4. Menentukan harga pokok persediaan produk jadi dan produk dalam proses yang disajikan dalam neraca

Pada saat manajemen dituntut untuk membuat pertangggung jawaban keuangan periodik, manajemen harus menyajikan laporan keuangan berupa neraca dan laporan laba rugi. Di dalam neraca, manajemen harus menyajikan harga pokok persediaan produk jadi dan harga pokok produk yang pada tanggal neraca masih dalam proses. Untuk tujuan tersebut, manajemen perlu menyelenggarakan catatan biaya produksi tiap periode.

Mulyadi (2015:17) menjelaskan bahwa metode penentuan kos produksi adalah cara memperhitungkan unsur-unsur biaya kedalam kos produksi, Dalam memperhitungkan unsur-unsur biaya kedalam kos produksi, terdapat 2 pendekatan yaitu:

Full costing merupakan metode penentuan biaya produksi yang memperhitungkan semua unsur biaya produksi ke dalam biaya produksi yang terdiri dari biaya bahan baku, biaya tenaga kerja langsung, dan biaya overhead pabrik, baik yang berperilaku variabel maupun tetap (Mulyadi, 2015), sedangkan menurut Bastian Bustami dan Nurlela (2013) Kalkulasi biaya penuh (full costing) merupakan suatu metode dalam perhitungan harga pokok yang dibebankan kepada produk dengan memperhitungkan seluruh biaya produksi baik yang bersifat variabel maupun yang bersifat tetap. Pada metode ini biaya overhead pabrik dibebankan kepada produk jadi atau ke harga pokok penjualan berdasarkan tarif yang ditentukan pada aktivitas normal atau aktivitas yang sesungguhnya terjadi. Metode full costing memperhitungkan biaya tetap karena biaya ini dianggap melekat pada harga pokok persediaan baik barang jadi maupun persediaan barang dalam proses yang belum terjual dan dianggap harga pokok penjualan jika produk tersebut sudah habis dijual.

Variabel costing merupakan metode penentuan biaya produksi yang hanya memperhitungkan biaya produksi yang hanya berperilaku variabel ke dalam biaya produksi, yang terdiri dari biaya bahan baku, biaya tenaga kerja langsung, dan biaya overhed pabrik variabel (Mulyadi, 2015).

\section{Harga Pokok Produksi}

Dibidang manufaktur, kegiatan utamanya adalah memproses bahan baku menjadi produk jadi dengan menggunakan fasilitas yang ada di pabrik. Semua biaya yang dikeluarkan dalam memproses menjadiproduk jadi disebut menjadi biaya produksi. Sedangkan harga pokokproduksi adalah sama dengan biaya bahan baku, upah langsung dan biaya overhead yang dikeluarkan dalam proses produksi. Pengertian lain tentang harga pokok produksi adalah biaya barang yang sudah diselesaikan selama satu periode atau disebut juga harga pokok produksi barang selesai disingkat dengan harga pokok produksi. ${ }^{6}$ Sedangkan biaya produksi adalah biaya yang terjadi untuk mengubah bahan baku menjadi barang jadi. Dapat ditarik kesimpulan bahwa harga pokok produksi adalah semua pengeluaran yang dilakukan oleh perusahaan untuk memproduksi menjadisuatu produk.

Penentuan harga pokok produksi memiliki tujuan utama yaitu sebagai dasar dalam menetapkan harga di pasar penjualan, untuk menetapan pendapatan yang didapat pada penukaran, serta sebagai alat untuk menilai efisiensi dari proses produksi.

Informasi mengenai harga pokok produksi untuk jangka waktu tertentu juga bermanfaat terutama bagi manajemen untuk:
a. Menentukan harga jual produk.
b. Melihat realisasi biaya produksi.
c. Menghitung laba atau rugi periodik. 
d. Menentukan harga pokok persediaan produk jadi dan dalam proses.

Harga pokok produksi terjadi karena adanya pembuatan produk dengan tujuan mengubah aktiva (berupa persediaan bahan baku) menjadi aktiva lain (persediaan produk jadi) atau pengorbanan atau biaya bahan baku yang akan membentuk harga pokok produksi.

\section{METODE}

Analisis data yang digunakan dalam penelitian ini adalah metode analisis deskriptif. Sugiono (2010:105) meyatakan metode analisis deskriptif, yaitu metode penelitian dengan cara mengumpukan datadata sesuai dengan yang sebenarnya kemudian data-data tersebut disusun, diolah dan dianalisis untuk dapat memberikan gambaran mengenai masalah yang ada.

1. Menentukan prosedur penentuan harga pokok menurut metode full costing, dengan cara:

$\begin{array}{ll}\text { Biaya Bahan Baku } & \mathrm{xxx} \\ \text { Biaya Tenaga Kerja Langsung } & \mathrm{xxx} \\ \text { Biaya Overhead Tetap } & \mathrm{xxx} \\ \text { Biaya Overhead Variabel } & \underline{\mathrm{xxx}+} \\ \text { Biaya Produksi } & \mathrm{xxx}\end{array}$

2. Menentukan prosedur penentuan harga pokok menurut metode variable costing, dengan cara:

$\begin{array}{ll}\text { Biaya Bahan Baku } & \mathrm{xxx} \\ \text { Biaya Tenaga Kerja Langsung } & \mathrm{xxx} \\ \text { Biaya Overhead Variabel } & \underline{\mathrm{xxx}+} \\ \text { Biaya Produksi } & \mathrm{xxx}\end{array}$

\section{HASIL DAN PEMBAHASAN}

\section{Perhitungan Harga Pokok Produksi Menurut Full Costing}

Harga pokok produksi menurut metode full costing yaitu menghitung seluruh biaya yang mempengaruhi proses produksi, seperti biaya bahan baku, biaya tenaga kerja dan biaya overhead pabrik baik yang bersifat variabel maupun bersifat tetap. Metode full costing adalah metode yang mengutamakan kedetailan dalam setiap penentuan biaya produksi. Berdasarkan data yang diterima dari perusahaan dalam menghitung harga pokok produksi lemari baju, terdapat beberapa biaya yang tidak dihitung secara rinci. Walaupun perusahaan secara sadar mengetahui bahwa biaya tersebut merupakan biaya yang dapat menambah Cost dalam proses produksi.

1. Biaya Bahan Baku

Bahan baku yang digunakan dalam pembuatan Lemari Baju pada usaha Mitra Mandiri Aluminium yaitu Aluminium dan Kaca. Perhitungan biaya bahan baku dapat dilihat pada tabel berikut :

Tabel. Perhitungan Biaya Bahan Baku

\begin{tabular}{|c|c|l|r|r|}
\hline No & Bahan Baku & Kebutuhan & \multicolumn{1}{c|}{ Harga } & \multicolumn{1}{|c|}{ Total Harga } \\
\hline 1 & Aluminium & 8 Meter & 190.000 & 1.520 .000 \\
\hline 2 & Kaca & 4 Lembar & 175.000 & 700.000 \\
\hline
\end{tabular}


Tasman S Haris dan Misnawati, Analisis Perhitungan Harga Pokok Produksi pada Mitra Mandiri Aluminium

\begin{tabular}{|l|l|}
\hline Total biaya bahan baku & $\mathbf{7 9 . 9 2 0 . 0 0 0}$ \\
\hline
\end{tabular}

Sumber: Data Yang Diolah (2021)

Sumber : Mitra Mandiri Aluminium, data diolah (2021)

2. Biaya Tenaga Kerja Langsung

Jumlah tenaga kerja pada usaha Mitra Mandiri Aluminium sebanyak 2 orang, upah di tentukan berdaraskan volume pekerjaan. total biaya tenaga kerja langsung dapat dilihat pada tabel berikut.

Tabel. Perhitungan Biaya Tenaga Kerja Langsung

\begin{tabular}{|c|l|c|c|c|}
\hline No & Bagian Pekerjaan & $\begin{array}{c}\text { Jumlah } \\
\text { Karyawan }\end{array}$ & Upah & $\begin{array}{c}\text { Total Biaya } \\
\text { (Rp) }\end{array}$ \\
\hline 1 & Pembuatan Rangka & 1 & 125.000 & 125.000 \\
\hline 2 & Finishing & 1 & 125.000 & 125.000 \\
\hline \multicolumn{3}{|c|}{ Jumlah Produksi } & $\mathbf{2 5 0 . 0 0 0}$ \\
\hline \multicolumn{2}{|c|}{ Total biaya tenaga kerja lansung } & $\mathbf{9 . 0 0 0 . 0 0 0}$ \\
\hline
\end{tabular}

Sumber: Data Yang Diolah (2021)

Sumber : Mitra Mandiri Aluminium, data diolah (2021)

3. Biaya Overhead Pabrik

Biaya overhead pabrik merupakan biaya-biaya yang dikeluarkan perusahaan selain dari biaya bahan baku dan biaya tenaga kerja langsung dalam proses produksi. Biaya overhead pabrik perusahaan antara lain berupa biaya listrik, biaya bahan penolong, biaya perawatan dan pemeliharaan mesin, dan biaya penyusutan.

a. Biaya Listrik

Biaya listrik dihitung berdasarkan waktu penyelesaian pembuatan lemari baju. Waktu penyelesaian 1 lemari baju sampai dengan 2 hari. Total biaya listrik dapat dilihat pada tabel berikut.

Tabel. Perhitungan Biaya Listrik

\begin{tabular}{|l|l|l|r|r|}
\hline Daftar Biaya & Biaya /Tahun & Biaya /Hari & $\begin{array}{c}\text { Waktu } \\
\text { Penyelesaian }\end{array}$ & $\begin{array}{l}\text { Total } \\
\text { Biaya }\end{array}$ \\
\hline Biaya Listrik & 2.760 .000 & 7.562 & 2 & 15.124 \\
\hline \multicolumn{2}{|c|}{ Jumlah Produksi } & 36 Unit \\
\hline Jumlah Biaya Listrik & & $\mathbf{5 4 4 . 4 6 4}$ \\
\hline
\end{tabular}

Sumber: Data Yang Diolah (2021) 
Sumber : Mitra Mandiri Aluminium, data diolah (2021)

Dari tabel diatas dapat diketahui jumlah biaya listik yang digunakan Mitra Mandiri Aluminium per unit dan penggunaan biaya listrik untuk membuat lemari baju periode 2019. Jumlah biaya listrik per unit sebesar Rp 15.124 sedangkan jumlah biaya listrik per tahun atau sebanyak 36 unit sebesar Rp. 544.464.

b. Biaya Bahan Penolong

Bahan penolong dalam membuat lemari baju pada usaha Mitra Mandiri Aluminium dapat dilihat dalam tabel berikut.

Tabel. Perhitungan Biaya Bahan Penolong

\begin{tabular}{|c|c|c|c|}
\hline Bahan Penolong & Kebutuhan & Harga & $\begin{array}{l}\text { Total Harga } \\
\text { (Rp) }\end{array}$ \\
\hline Engsel & 1 Batang & 60.000 & 60.000 \\
\hline Shochase & 3 Meter & 16.500 & 49.500 \\
\hline Holow Tanduk & 9 Meter & 24.500 & 220.500 \\
\hline Roda & 1 Dos & 55.000 & 55.000 \\
\hline Join Pipa & 1 Set & 15.000 & 15.000 \\
\hline Pipa Gantungan & 1 Meter & 11.250 & 11.250 \\
\hline Siku & 10 Meter & 3.500 & 35.000 \\
\hline $\mathrm{U} 3 / 8$ & 10 Meter & 3.500 & 35.000 \\
\hline Kunci Lemari & 2 Pcs & 15.000 & 30.000 \\
\hline Tarikan Pintu & $2 \mathrm{Pcs}$ & 20.000 & 40.000 \\
\hline Karet Lemari & 1 Roll & 75.000 & 75.000 \\
\hline Paku Ripet & 1 Dos & 45.000 & 45.000 \\
\hline Kaso & 1 Meter & 10.000 & 10.000 \\
\hline \multicolumn{3}{|c|}{ Jumlah Biaya Bahan Penolong per Unit } & 681.250 \\
\hline \multicolumn{3}{|c|}{ Jumlah Produksi } & 36 Unit \\
\hline \multicolumn{3}{|c|}{ Total biaya bahan penolong } & 1.031 .250 \\
\hline
\end{tabular}

Sumber: Data Yang Diolah (2021)

Sumber : Mitra Mandiri Aluminium, data diolah (2021)

c. Biaya perawatan dan pemeliharaan mesin

Mitra Mandiri Aluminium pada tahun 2020 mengganti oli mobil sebanyak 7 kali dengan total harga sebesar Rp 3.850.000, mengganti kampas mobil sebanyak 6 kali dengan total harga Rp 1.800.000, mengganti Ban mobil sebanyak 4 kali dengan total harga Rp 1.900.000. Perhitungan biaya perawatan dapat dilihat pada tabel berikut.

Tabel. Perhitungan Biaya Perawatan

\begin{tabular}{|c|c|r|r|}
\hline Daftar Biaya & kebutuhan & \multicolumn{1}{l|}{ Harga } & \multicolumn{1}{|l|}{ Total Biaya } \\
\hline Oli Mobil & 7 & 550.000 & 3.850 .000 \\
\hline Oli Gengset & 2 & 35.000 & 70.000 \\
\hline Kampas & 6 & 300,000 & 1.800 .000 \\
\hline
\end{tabular}


Tasman S Haris dan Misnawati, Analisis Perhitungan Harga Pokok Produksi pada Mitra Mandiri Aluminium

\begin{tabular}{|c|c|c|c|}
\hline Ban & 4 & 475.000 & 1.900 .000 \\
\hline Jumlah Biaya Perawatan & & $\mathbf{7 . 6 2 0 . 0 0 0}$ \\
\hline
\end{tabular}

Sumber: Data Yang Diolah (2021)

Sumber : Mitra Mandiri Aluminium, data diolah (2021)

d. Biaya penyusutan

Berikut ini rumus perhitungan biaya penyusutan.

$$
\text { Depresiasi }=\frac{\text { Harga Perolehan }- \text { Nilai Residu }}{\text { Umur Ekonomis }}
$$

Berdasarkan rumus perhitungan di atas, maka dapat diketahui biaya penyusutan per tahunnya. Perhitungan biaya penyusutan dapat dilihat dalam tabel berikut.

Tabel. Perhitungan Biaya Penyusutan

\begin{tabular}{|l|c|l|r|r|r|r|}
\hline \multicolumn{1}{|c|}{ Alat } & Tahun & $\begin{array}{l}\text { Jumlah } \\
\text { Unit }\end{array}$ & $\begin{array}{l}\text { Harga } \\
\text { Perolehan }\end{array}$ & $\begin{array}{l}\text { Nilai } \\
\text { Residu }\end{array}$ & $\begin{array}{l}\text { Usia } \\
\text { Ekonomis }\end{array}$ & $\begin{array}{l}\text { Biaya } \\
\text { Penyusutan }\end{array}$ \\
\hline Bangunan & 2017 & 1 & 45.000 .000 & 32.056 .875 & 10 & 1.294 .312 \\
\hline Mobil & 2017 & 1 & 70.000 .000 & 29.531 .250 & 8 & 5.046 .875 \\
\hline Kompresor & - & 1 & 1.200 .000 & - & 4 & 300.000 \\
\hline Mesin Pemotong & - & 1 & 4.750 .000 & - & 4 & 1.187 .500 \\
\hline \multicolumn{1}{|c|}{ Bor } & - & 2 & 700.000 & - & 4 & 175.000 \\
\hline Bor Cas & - & 1 & 1.400 .000 & - & 4 & 350.000 \\
\hline Gurinda & - & 3 & 1.650 .000 & - & 4 & 412.500 \\
\hline Klemriped & - & 5 & 550.000 & - & 4 & 137.500 \\
\hline Gunting & - & 3 & 3.000 .00 & - & 4 & 750.000 \\
\hline Kikir & - & 4 & 300.000 & - & 4 & 75.000 \\
\hline Tang & - & 1 & 210.000 & - & 4 & 52.500 \\
\hline Gengset & - & 1 & 4.500 .000 & - & 4 & 1.125 .000 \\
\hline Inventer & & 3 & 90.000 & - & 4 & 22.500 \\
\hline Meteran & & & & & $\mathbf{1 0 . 9 7 2 . 4 3 7}$ \\
\hline
\end{tabular}

Sumber: Data Yang Diolah (2021)

Sumber : Mitra Mandiri Aluminium, data diolah (2021)

Berdasarkan tabel diatas dapat diketahui bahwa biaya penyusutan mesin, bangunan, kendaraan dan peralatan selama satu tahun adalah sebesar Rp 10.972.437,-.Perhitungan harga pokok produksi pada penelitian ini menggunakan metode full costing dengan menjumlahkan semua unsur-unsur biaya dalam proses produksi. Berdasarkan biaya-biaya tersebut perhitungan harga pokok produksi menggunakan metode full costing dapat dilihat sebagai berikut: 
Tasman S Haris dan Misnawati, Analisis Perhitungan Harga Pokok Produksi pada Mitra Mandiri Aluminium

Tabel. Perhitungan Harga Pokok Produksi Dengan Metode Full Costing

\begin{tabular}{|l|r|r|}
\hline \multicolumn{1}{|c|}{ Jenis Baya } & \multicolumn{2}{c|}{ Total Biaya } \\
\hline Biaya Bahan Baku & & 79.920 .000 \\
\hline Biaya Tenaga Kerja Langsung & & 9.000 .000 \\
\hline Biaya Overhead Pabrik Variabel : & & \\
\hline Biaya Bahan Penolong & 544.464 & \\
\hline Biaya Listirk & & \\
\hline Biaya Overhead Pabrik Tetap : & 7.620 .000 & \\
\hline Biaya Perawatan Dan Pemeliharaan & $\mathbf{1 0 . 9 7 2 . 4 3 7}$ & $\mathbf{2 0 . 1 6 8 . 1 5 1}$ \\
\hline Kendaraan & & $\mathbf{1 0 9 . 0 8 8 . 1 5 1}$ \\
\hline Biaya Penyusutan & & $\mathbf{3 6}$ Unit \\
\hline Jumlah Biaya Overhead Pabrik & & $\mathbf{3 . 0 3 0 . 2 2 6}$ \\
\hline Total Biaya Produksi & & \\
\hline Jumlah Produk Yang Dihasilkan & & \\
\hline Harga Pokok Produksi Per Set & & \\
\hline
\end{tabular}

Sumber: Data Yang Diolah (2021)

Sumber : Mitra Mandiri Aluminium, data diolah (2021)

Tabel diatas menunjukkan bahwa harga pokok produksi yang dihasilkan dengan menggunakan metode full costing pada usaha Mitra Mandiri Aluminium adalah sebesar Rp 3.030.226,-

\section{Perhitungan Harga Pokok Produksi Menurut Variable Costing}

Perhitungan harga pokok produksi menurut Variable Costing merupakan metode penentuan Cost produksi yang hanya memperhitungkan biaya produksi yang berperilaku variabel ke dalam Cost produksi, yang terdiri dari biaya bahan baku, biaya tenaga kerja langsung, dan biaya overhead pabrik variabel. Biayabiaya yang diakui dalam perhitungan harga pokok produksi menggunakan metode variable costing:

1. Biaya bahan baku dengan total biaya bahan baku yang dikeluarkan perusahaan selama 1 tahun yaitu Rp 79.920.000,-

2. Biaya tenaga kerja langsung yang dikeluarkan sebesarRp9.000.000,-

3. Biaya overhead pabrik yang dihitung menggunakan metode variabel costing yaitu biaya bahan penolong Rp 1.031.250, biaya listrik Rp 544.464. Jadi, total biaya overhead pabrik variabel sebesar Rp 1.575.714

Berdasarkan biaya-biaya tersebut perhitungan harga pokok produksi menggunakan metode variabel costing dapat dilihat pada tabel berikut:

Tabel. Perhitungan Harga Pokok Produksi Dengan Metode Variable Costing

\begin{tabular}{|l|l|r|}
\hline \multicolumn{1}{|c|}{ Jenis Baya } & Total Biaya \\
\hline Biaya Bahan Baku & & 79.920 .000 \\
\hline Biaya Tenaga Kerja Langsung & & 9.000 .000 \\
\hline Biaya Overhead Pabrik Variabel : & & \\
\hline
\end{tabular}


Tasman S Haris dan Misnawati, Analisis Perhitungan Harga Pokok Produksi pada Mitra Mandiri Aluminium

\begin{tabular}{|l|r|r|}
\hline Biaya Bahan Penolong & 1.031 .250 & \\
\hline Biaya Listirk & 544.464 & \\
\hline Jumlah Biaya Overhead Pabrik & & \\
\hline Total Biaya Produksi & & 90.495 .714 \\
\hline Jumlah Produk Yang Dihasilkan & & 36 Unit \\
\hline Harga Pokok Produksi Per Set & & \\
\hline
\end{tabular}

Sumber: Data Yang Diolah (2021)

Sumber : Mitra Mandiri Aluminium, data diolah (2021)

Tabel diatas menunjukkan bahwa harga pokok produksi yang dihasilkan dengan menggunakan metode variabel costing pada Usaha Mitra Mandiri Aluminium adalah sebesar Rp 2.513.769,-.

\section{SIMPULAN}

Berdasarkan hasil analisis dan pembahasan yang dilakukan penulis, maka hasil penelitian dapat disimpulkan bahwa Terdapat perbedaan perhitungan harga pokok produksi menurut metode full costing, dan metode variable costing, hal ini terjadi karena adanya perbedaan pembebanan biaya., metode variable costing hanya memperhitungkan BOP variabel saja. Sedangkan metode full costing akan membebankan semua BOP baik yang bersifat tetap maupun yang bersifat variabel. Karena itu, metode full costing lebih menguntungkan bagi pihak perusahaan karena akan membebankan semua biaya-biaya yang mempengaruhi proses produksi, sehingga menghasilkan harga pokok produksi yang lebih akurat. Jadi dalam perhitungan menggunakan metode full costing menunjukkan bahwa harga pokok produksi yang dihasilkan pada usaha Mitra Mandiri Aluminium lebih besar dan lebih layak di bandingkan menggunakan metode variabel costing.

\section{DAFTAR PUSTAKA}

Bustami, Bastian dan Nurlela 2013, Akuntansi Biaya tingkat lanjutan, Jakarta: Graha Ilmu.

Ekmal, 2010, Analisis Penentuan Harga Pokok Produksi Rumah Pada PT.Rozaqqindo Jaya Pekanbaru, UIN SUSKA RIAU, Pekanbaru.

Hansen dan Mowen. (2012). Akuntansi Manajerial. Buku 1, Edisi 8. Salemba Empat: Jakarta.

Mulyadi. 2014. Akuntansi biaya. Unit Penerbit Dan Percetakan Akademi Manajemen Perusahaan YKPN, Yogyakarta.

Mulyadi. 2015, Akuntansi Biaya Edisi 5, Yogyakarta: UPP-STIM YKPN.

Putra, Indra Mahardika. 2018, Akuntansi Biaya, Quadrant, Yogyakarta. Sugiyono. (2014). Metode penelitian bisnis. Bandung: Alfabeta 